\title{
A question of time - or academic subjectivity?
}

\author{
It's just a question of time / It's running out for you (Gore 1986)
}

A bit over 30 years ago an electronic band Depeche Mode released a single $A$ Question of Time, written by one of the band members Martin Gore (1986). The lyrics speak terrifically well to the present academic life. Time, indeed, seems to be in question as we lead our lives, simultaneously carrying out research and applying funding for it, providing teaching and supervision, taking care of administrative duties, participating in scientific meetings and events, acting in positions of trust, taking up editorships and peer reviewing, organizing conferences, seminars, workshops, sessions and panels, giving back to individuals and communities engaged in our research projects, taking stands in academic and popular debates, circulating research results to different audiences - and living our personal lives somewhere in between. 'Finding the time' is what academics often struggle with, when considering interesting new projects and activities as well as apologizing for not being able to fulfil commitments in due course.

Yet the mentioned piece of music is not concerned of time as something we may run out of or have hard time finding. Rather, the song is about subject formation. It talks about the haunting, corrupt forces that seek to mould us to meet their own ends and turn promising young subjects into bulk.

It's just a question of time / Before they lay their hands on you / And make you just like the rest / They've persuasive ways / And you'll believe what they say / It won't be long until you'll do / Exactly what they want you to

These two facets of time, intertwined, have emerged in our publishing development project Julkea! [Dare!], coming to an end of its first year. It is a two-year "bold initiative", funded by the Kone Foundation that promotes academic research, culture, art and the popularisation of research with the specific purpose of "providing alternatives to the mainstream". In the project, three scientific societies - Society for Regional and Environmental Studies, Geographical Society of Finland, and Finnish Society for Environmental Social Science - and the referee journals they publish (including Fennia), are working together with and for the Finnish academic society, with the aims to advance publishing practices, infrastructures, communities, and conventions in the fields of geography and regional and environmental studies. The project is carried out in alliance with related national efforts seeking to foster open science by means of supporting society-based publications in Finland (Kotilava) in response to the Open Science and Research Initiative 2014-2017 launched by the Ministry of Education and Culture:

The objective is for Finland to become one of the leading countries in openness of science and research by the year 2017 and to ensure that the possibilities of open science will be widely utilised in our society.

The Finnish academic publication scene is quite different from that in many other countries. Nearly all academic journals are still published by scientific societies, as non-profit organizations relying on the support of their members, state subsidies and external funding, mainly independently of commercial publishing houses. Universities and research institutes assume some responsibility for this publishing tradition, as their employees and students act in positions of trust in the societies, publishing the journals as part of their academic work. This implicit support has, however, started to wane out, increasingly during the 2000s as the universities have been transferred from State accounting offices into independent legal entities separate from the State, acting either as corporations under public law or foundations under private law. The general aim of the reform was to strengthen the autonomy of the universities, yet critical interpretations point towards neoliberalization (e.g. Moisio 2009; Kouhia \& Tammi 2014; Ylöstalo 2014). Among other things, the recent developments include establishing more and more individualistic and productive academic subjectivities, which gets us back to questions of time and its disempowering features. 
I can see them now / Hanging around / To mess you up / To strip you down / And have their fun / With my little one

The first half of the Julkea! project has taught us that many people in the Finnish academy warmly welcome the efforts to develop the current publishing system, to meet the demands of the present academic work, instead of letting it collapse and be replaced by commercial formats. Institutions, similarly, express their support for non-commercial open publishing, at least if it does not expect their commitment or practical support. The current process where society-based journals are seeking to build a national consortium as a cost structure for non-profit open access publishing, enforced by the Federation of Finnish Learned Societies and the National Library, has proven enlightening in this regard. The key actors - university libraries - are deliberating the request for voluntary payments in a situation where international commercial publishing houses demand high payments from them, which does not make it easy for the libraries to agree on shared responsibility.

In the present situation, researchers are particularly aware of and annoyed by the measuring systems used to direct their agencies - to publish rather in journals than books, internationally before nationally, in publications with high impact figures, and so on (cf. Jones 2017; Ruez 2017). At the same time, Finnish scholars find less and less time to engage with the society-based publishing system that requires even more voluntary work than academic publishing in general. Running the societies, editing the journals and reviewing for them come on the top of everything else - the everything that needs to be done in time, albeit often running late.

We suggest that this experienced shortage of time, often very concretely present in the form of schedules and deadlines and overlapping workloads, is tied to the academic subjectivities presently fostered in universities and in the academy as a whole. Granted that scholarly work has always involved devotion and intensities, pressures from states and research funders, and mutual competition, there is something paradoxical in how we currently see and feel ourselves as scholars hooked between critical minds and competing agencies. Instead of using time for matters that require it, time seems to be using us, to purposes that cannot be explained in academic terms. We will give one example that resonates strongly with what Michael Jones (2017) brings up in his reflection on publishing, in the discussion series of this issue of Fennia.

The revise and resubmit processes, commonly used in journals with a high rejection rate, take plenty of time from the many scholars involved in them. It is not exceptional that the editors and authors work together for years, with an alternating group of reviewers, before they can agree - or disagree - on the version that can be published. The time spent is not necessarily proportionate with the gains in quality, while the papers surely transform in the process, as the introduction to the discussion series 'On Publishing', in this issue, highlights (Riding \& Kallio 2017). This results on one hand from that, peer reviewers do not always have the best expertise regarding the papers, and the time for reading the manuscripts and writing the reports is restricted. There are just too many manuscripts continually under review to meet the ideal criteria and, thus arguably, all academic journals struggle with finding reviewers and receiving review reports in reasonable time. This is pointed at by Simon Springer and the ACME collective (2017) who, as part of their editorial work, are encouraging researchers to actively 'make time' for peer reviewing in OA journals, while acknowledging the overburdening and harsh prioritization of responsibilities in the neoliberal academia. Moreover, the journal editors dealing yearly with tens of papers are neither experts of everything, as they apparently should be to serve the amplifying number of submission. Editors may hence find it challenging to take an active role between the reviewers and the authors, to decide on the revisions needed for quality improvement.

Due to these practical facts, the R\&R practice originally intended for assessing and improving the quality of publications may end up serving the publication process itself; the process eats time whilst the time for developing better papers lessens. This is not beneficial for anyone, yet the reality many of us know of and live with. The question is ever more essential to scholars coming from beyond the Anglophone world. In her reflection on academic publishing Sara Fregonese (2017) - a fluent English speaker working in a British university and doing research on several languages - notes that nonnative speakers of English may face additional obstacles in review processes, ranging from picky 
comments on writing style to calling into question field work on languages foreign to the reviewer, which lengthen publication processes further. Approaching the same dilemma, Derek Ruez (2017) suggests that new publishing practices are needed for leveling the playing field for non-Anglophone scholars and to dispute the Anglo-hegemony of the academy. These ideas and endeavors are not completely novel and they have been presented by others in previous discussions on socially just academic publishing, yet concrete measures remain few and little has changed in the big picture.

A lesser amount of papers and journals would allow that authors, editors and reviewers could use their time for developing good quality and socially just publications, instead of being exhausted by their large quantity (cf. Batterbury 2017; Finn et al. 2017). This would ideally involve language editing as part of the standard process, where necessary. Yet research funders and institutions do not easily share the ideas 'less is more' or 'plurality as a value in itself' but are, instead, constantly asking for more quantifiable research results as their performance depends on that as well, stemming from the competition state ideology (Moisio 2009; Paasi 2013). So being, have we no choice but to be used by time in the hectic and overcrowded publishing industry, producing more and more peer reviewed papers that, in their quantity, may not take things forward any better than a smaller number of publications could do? Are we completely caught by the system as it is, in Simon Batterbury's (2017, 175) words, "strongly linked to the individual reputation of authors, their prestige and job and promotion prospects"? Publish 'til you drop?

A grim picture arises from this thinking. There seems to be no one there to be blamed, nowhere to appeal. In contrast with Depeche Mode's song, and faithfully to Foucault, 'they' cannot be seen hanging around us, messing up our new enthusiastic students and stripping scholars down from solidarities and alternative attitudes. The forces that make us so busy that we don't have time for the matters that perhaps matter the most are, first, too global to be seen up close, yet at the same time too close, internalised in our academic selves.

We don't have a solution, and we are not going to pretend that we have one. In our different stages of academic life, we are both experiencing time as a hinder rather than a resource, and we have not found overpowering weapons of the weak to combat the dominating state of affairs. Yet we believe that by paying attention to the paradoxical elements of our shared academic lives it is possible to make visible some sources of the experienced (socially constituted) lack of time and, perhaps also, draw attention to alternative resources that provide for using time in ways we choose to, and concurrently, to contest the faceless forces shaping us towards docile profitable academic subjecthood. Hanging on to this fragile thought, we continue our commitment to developing better publishing policies and practices, as well as science politics based on plural values, even if we often have to admit: Apologies but I just don't have the time for this right now.

This issue of Fennia includes two peer reviewed research articles, one reflective book review, and a discussion series 'On Publishing', introduced in more detail in a separate editorial text (Riding \& Kallio 2017). The first article is by Matthew Sawatzky and Moritz Albrecht, based at the University of Eastern Finland in Joensuu, drawing from their original research on Reunion Island. They have taken the French Overseas Department and Region as a case study to explore the application potential of local energy governance processes, including aspects shaping regional translation of national and EU policy, and the potential effects of energy transition. The second research article is by Christoph D. D. Rupprecht from the Research Institute for Humanity and Nature in Kyoto, Japan. It engages with more-than-human cities as spaces of coexistence, arguing for a better recognition of informal green space as territories of encounter allowing for conciliatory engagements and interspecies interactions. The paper presents a rare approach in the present literature by, instead of juxtaposing humanity with the non-human and materiality, sets out to ask and explore what fruitful coexistence may mean in urban space, and how the individuals, collectives and institutions concerned about their cities could better sustain them by acknowledging the different capacities of non-human actors and elements. The book review included in our Reflections section, by Elisa Pascucci at the University of Tampere in Finland, engages with ongoing refugee situations, policies and practices in the Mediterranean region, broadly understood, and offering a critical approach to how Alexander Betts and Paul Collier couple humanitarian principles and capitalist economic development in their recent co-authored book 
Refuge. The critical discussion series on academic publishing includes contributions from Michael Jones, Simon Batterbury, Derek Ruez, Sara Fregonese, and the editors of Human Geography (Finn et al. 2017) and ACME (Springer et al. 2017), preceded by an editorial introduction (Riding \& Kallio 2017).

We hope that this issue of Fennia will be widely read and broadly circulated among geographers and beyond. The journal wishes to acknowledge the engaged work of all authors and peer reviewers involved in the publication processes - thank you for working with us with the 'quality rather than quantity' agenda in mind!

KIRSI PAULIINA KALLIO

FENNIA EDITOR-IN-CHIEF

PIETA HYVÄRINEN

JULKEA! PROJECT COORDINATORT

\section{REFERENCES}

Batterbury, S. (2017) Socially just publishing: implications for geographers and their journals. Fennia 195(2) 175-181. https://doi.org/10.11143/fennia.66910

Finn, J.C., Peet, R., Mollett, S. \& Lauermann, J. (2017) Reclaiming value from academic labor: commentary by the Editors of Human Geography. Fennia 195(2) 182-184. https://doi.org/10.11143/fennia.66683

Fregonese, S. (2017) English: lingua franca or disenfranchising? Fennia 195(2) 194-196. https://doi.org/10.11143/fennia.67662

Gore, M. (1986) A question of time. Produced by Depeche Mode, Gareth Jones Daniel Miller, with Mute Records.

Jones, M. (2017) Can research quality be measured quantitatively? On quality of scholarship, numerical research indicators and academic publishing - experiences from Norway. Fennia 195(2) 164-174. https://doi.org/10.11143/fennia.66602

Kouhia, A.\&Tammi, T.(2014)Akateemisen kapitalisminuusliberaalitutkijasubjektikasvatustieteellisessä tohtorikoulutuksessa. Kasvatus \& Aika 8(2) 22-39.

Moisio, S. (2009) Suomen valtion aluerakenteen muuntautuminen: teoreettisia merkintöjä ja empiirisiä havaintoja. Politiikka 51(3) 155-173.

Open Science and Research Initiative 2014-2017. https://openscience.fi/

Paasi, A. (2013) Fennia: positioning a 'peripheral' but international journal under the condition of academic capitalism. Fennia 191(1) 1-13. https://doi.org/10.11143/7787

Riding, J. \& Kallio, K. P. (2017) Six sideways reflections on academic publishing. Fennia 195(2) 161-163. https://doi.org/10.11143/fennia.67833

Ruez, D. (2017) Evaluating otherwise: hierarchies and opportunities in publishing practices. Fennia 195(2) 189-193. https://doi.org/10.11143/fennia.66884

Springer, S., Houssay-Holzschuch, M., Villegas, C. \& Gahman, L. (2017) Say 'Yes!' to peer review: Open Access publishing and the need for mutual aid in academia. Fennia 195(2) 185-188. https://doi.org/10.11143/fennia.66862

Ylöstalo, H. (2014) Työntekijäkansalaisia vai maailman muuttajia?: opiskelijat uusliberalistisessa yliopistossa. Sukupuolentutkimus 27(4) 5-16. 